\title{
Environmental Education Infographics by Instagram: Digital Learning Material Increasing Motivation During the Covid-19 Pandemic
}

\author{
Habibah Rahmawati ${ }^{1}$, Rizhal H. Ristanto ${ }^{2}$, Mieke Miarsyah ${ }^{3}$ \\ 1,2,3 Universitas Negeri Jakarta, Indonesia
}

habibahrahmawati_1312819015@mhs.unj.ac.id

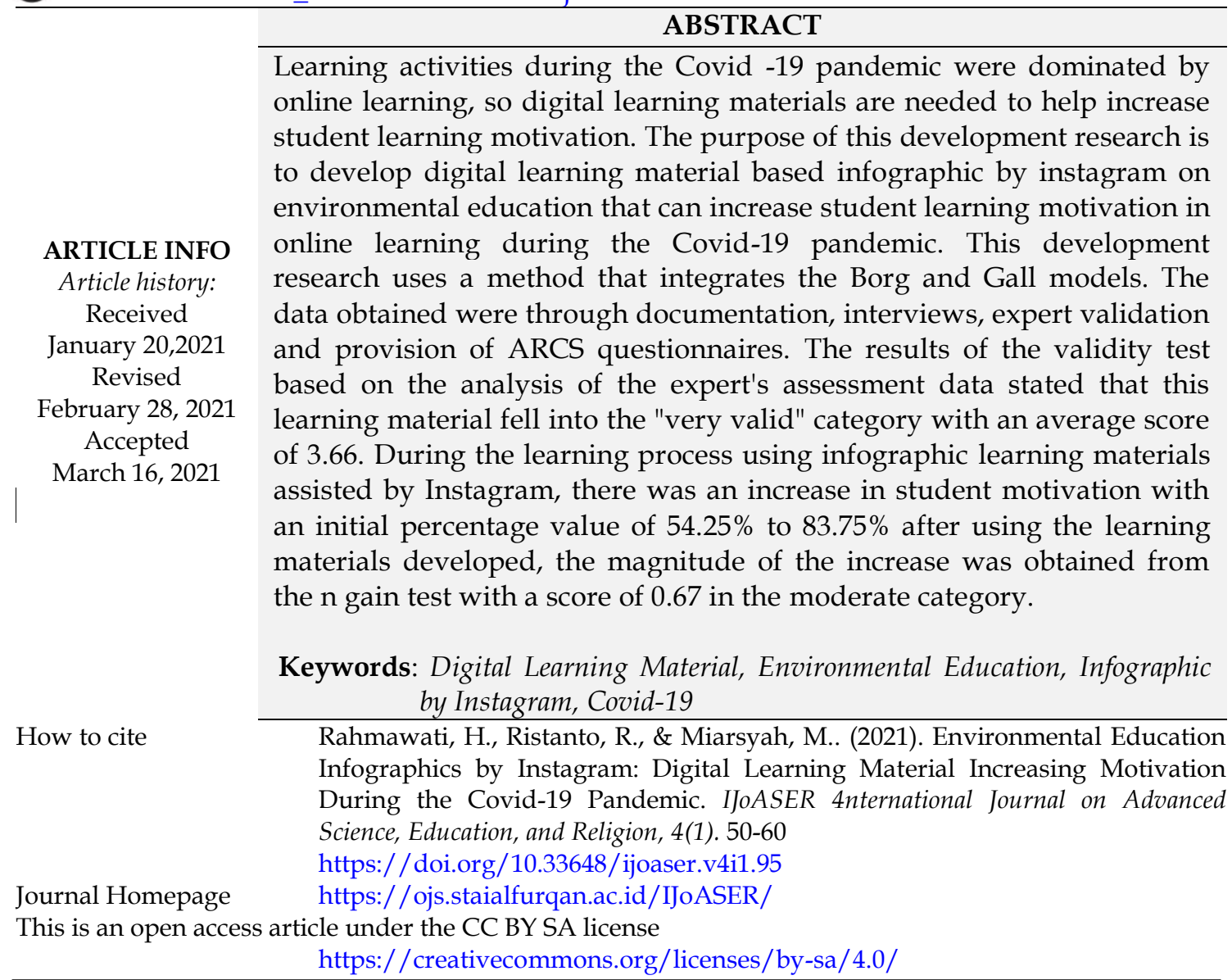

\section{INTRODUCTION}

The Covid-19 pandemic is a major challenge for all systems in the world, including the education system, according to claims from the United Nations (UN) that one of the sectors that has a major impact on the Covid-19 pandemic is the education sector (Bandyopadhyay, 2020; Wang et al., 2020). The new policy that has become the biggest change in learning activities is the online "Learning from Home" program. Elearning is the right option to guarantee the continuity of learning activities during the Covid-19 pandemic (Cahyani et al., 2020).

Online learning during the Covid-19 pandemic produced a variety of perspectives from educators and students. During the adaptation period, the transition from offline learning to online learning at the beginning of the pandemic was very difficult and burdensome for most educators and students (Guo \& Li, 2020). The difficulties that occur are because they are not familiar with the use of digital in 
learning activities for most educational institutions (Basilaia \& Kvavadze, 2020; Rasmitadila et al., 2020). Online learning activities have limitations in interactions between students and educators, so learning will feel monotonous due to a lack of innovation from educators (Adnan, 2020; Mufida et al., 2020). The limitations of the description of the material are also the cause of the difficulty of educators in presenting learning material in the process of understanding students. During the pandemic, digital learning material of environmental education based infographic by instagram is indispensable in online learning activities that serve to support the achievement of the goals of learning (Ali Sadikin, 2020).

Digital Learning Materials (DLM) are materials that contain various content such as animation, infographics, written text, audio, audio visuals, and various interactive content digital that can be used as an alternative to improve student digital learning activities. DLM is very suitable for online learning activities, especially during the Covid-19 pandemic (König et al., 2020; Nieto-Márquez et al., 2020; Zwart et al., 2017). One of DLM that can be used in online learning activities is infographic-based learning materials with Instagram assistance.

Infographics are a technique in presenting information visually or graphically which aims to make it easier for readers to obtain information (Juliyanto \& Rusdi, 2019; Listya, 2018). The use and utilization of infographics in learning activities aims to facilitate students in the process of understanding material and help in making learning activities effective (Bystrova, 2020). At this time many people are more interested in information that is packaged creatively and attractively without reducing the information conveyed (Ria et al., 2018). The availability of a variety of visuals in the infographic can cause students to better understand the subject matter presented. Infographics provide various images that are expected to make students interested in reading. The picture is a visualization of the subject matter with the aim of students easily understanding the material.

Instagram is a social media that can be used in online learning activities because it can increase the motivation of students in learning. This is because Instagram provides various channels that can have a positive impact on fun learning activities (Abel \& McQueen, 2020; Bestari et al., 2020; Lin et al., 2017). In addition, Instagram, which is a social media that is quite attractive to teenagers, has great potential in delivering interesting information to teenagers (Iman, 2020; Jayani, 2020; Juliyanto \& Rusdi, 2019).

According to previous research, the Instagram application provides students the opportunity to get animated videos and infographics on learning activities so that learning can be more fun (Rohim \& Yulianti, 2020). The use of infographics as learning materials can affect the learning achievement of students in the cognitive domain (Umami \& Budi, 2016). The use of infographics in learning activities is said to be effective because it affects the memory and reasoning of students. This can be used by educators to develop infographic-based learning materials as an effort to support students' understanding (Mansur \& Rafiudin, 2020; Wulandari et al., 2019).

Several previous studies related to learning activities that utilize Instagram-based media show that this use can help students in the learning process. This shows that digital learning materials are needed in learning activities to achieve learning goals. In addition, the conditions of learning activities during the pandemic are very supportive of the use of digital learning materials to increase student motivation.

Based on this, the purpose of this study was to develop digital learning material based infographic by instagram on environmental education that can increase student 
learning motivation in online learning during the Covid-19 pandemic. This research and development study is aimed at making it easier for students in the process of understanding the material, helping students in visualizing learning material, so it can be easier to remember and understand. The carrying of this learning material is also very suitable for use in online learning during a pandemic.

\section{METHOD}

This study used the research and development $(\mathrm{RnD})$ method with references from the modified opinion of Borg and Gall (Gall et al., 2006). The purpose of this study was to develop infographic-based environmental education learning materials through Instagram to increase student learning motivation during the Covid-19 pandemic. The research was conducted at SMPN 23 South Tangerang from October to November 2020 in the 2020/2021 school year.

In this study, data collection techniques were obtained through documentation, interviews, expert validation and provision of ARCS instruments (Attention, Relevance, Confidence, Satisfaction), and questionnaires. The questionnaire here functions in collecting data related to the feasibility of learning materials developed by learning media that are made and will be answered by respondents related to learning, including: material experts, media experts, teachers and students as users. The research design used Group Pre-Test and Post-test Design. Researchers used the stages of development according to Borg and Gall with modifications, namely 1.) Conducting analysis, 2.) Planning development, 3.) Developing products, 4.) Conducting limited trials (Gall et al., 2006).

The first stage, in the analysis treatment, the researcher collected data from various relevant references and made observations. In the second stage, namely doing development planning. In this case, researchers have started to make learning materials for environmental education based on infographics with the help of Instagram. Furthermore, the researcher prepared environmental education learning materials that would be implemented in science learning. Implementation of environmental education that is used is in Theme 3, topic 10 Energy material by integrating science material Chapter 6 Energy in Living Systems.

In the third stage, the development of digital learning material of environmental education based infographic by instagram is carried out by testing product development through a logical validation design with validation types of media experts, validation of material experts, and validation of educators as teachers. Validation is carried out by experts who have relevant expertise in the field of study of learning material development. After the experts validate the learning materials, then the learning materials developed will be carried out with limited trials for students (Ichsan et al., 2019).

Table 1. Expert Validation Criteria (Ratumanan \& Laurens, 2016)

\begin{tabular}{cc}
\hline Score Validation & Criteria \\
\hline $3,25<x \leq 4,00$ & Very Valid \\
$2,50 \leq x \leq 3,25$ & Valid \\
$1,75<x<2,50$ & Less Valid \\
$1,00<x<1,75$ & Not Valid \\
\hline
\end{tabular}

Experimental Design Model to Test Students' Motivation 
In development research, product testing is an important stage after completing the product design stage. The trial activity in this study was carried out with the aim of being able to find out whether the Instagram-assisted infographic-based environmental education learning materials developed could support student learning or not support student learning.

The trial design in this study was to determine the increase in learning motivation of students by using Instagram-based infographic-based environmental education learning materials, namely by means of experimentation. The research design used was one group pretest-posttest, this design consisted of a predetermined group. In this design, tests were carried out twice. The first test was performed before being given treatment (pre-test) and the second test was carried out after treatment (post-test). The research pattern of the one group pretest-posttest design method is as follows (Sugiyono, 2012):

Information :

$$
\mathrm{O}_{1} \times \mathrm{O}_{2}
$$

$\mathrm{O}_{1}=$ Pre-test score (motivation before implementing digital learning material of environmental education based infographic by instagram)

$\mathrm{X}=$ Digital learning material of environmental education based infographic by instagram

$\mathrm{O}_{2}=$ Post-test score (motivation after implementing digital learning material of environmental education based infographic by instagram)

Student motivation data processing is done by analyzing the percentage score of each instrument item which is grouped based on its aspects and indicators. The calculation is done through the following equation:

$$
\%=\left(\frac{n}{N}\right) \times 100 \%
$$

Description :

$\mathrm{n} \quad=$ Score obtained

$\mathrm{N}=$ Sum of all maximum scores

To determine the effectiveness of the application of Instagram-assisted infographic teaching materials in learning activities, researchers used gain data analysis. The calculation is done using the gain normalization test equation as follows:

$$
\mathrm{N}-\text { gain }=\quad \frac{\text { Final score }(\text { post test })-\text { Initial score }(\text { pre test })}{\text { Maximum score }- \text { Initial score }(\text { pre test })}
$$

Table 2. Criteria for N-Gain Value

\begin{tabular}{cc}
\hline Standard Gain Value & Description \\
\hline$\geq 0,7$ & High \\
\hline $0,7 \geq g \geq 0,3$ & Moderate \\
\hline$\leq 0,3$ & Low \\
\hline
\end{tabular}




\section{RESULT AND DISCUSSION}

Table 3. Results of the Total Average Score of Expert Validation

\begin{tabular}{|c|c|c|c|c|c|}
\hline No. & Validator & Suggestion & Score & Average Score & Category \\
\hline 1 & $\begin{array}{l}\text { Media } \\
\text { Expert }\end{array}$ & $\begin{array}{l}\text { - The writing must be tidied up and } \\
\text { slightly enlarged so that it can be read } \\
\text { clearly } \\
\text { - The use of color is made more contrasted } \\
\text { so that it is interesting and helps in } \\
\text { facilitating students' understanding }\end{array}$ & 3,53 & \multirow{3}{*}{3,66} & \multirow{3}{*}{$\begin{array}{l}\text { Very } \\
\text { Valid }\end{array}$} \\
\hline 2 & $\begin{array}{l}\text { Material } \\
\text { Expert }\end{array}$ & $\begin{array}{l}\text { - To include all existing sub-topics related } \\
\text { to the implementation of environmental } \\
\text { education in science learning. }\end{array}$ & 3,70 & & \\
\hline 3 & $\begin{array}{l}\text { Teacher } \\
\text { of Class }\end{array}$ & $\begin{array}{l}\text { - Interactive activities in the comments } \\
\text { column should be more conducive so } \\
\text { that educators do not have difficulty } \\
\text { correcting student answers }\end{array}$ & 3,75 & & \\
\hline
\end{tabular}

In several regions in Indonesia, educators are required to implement environmental education in science and social studies learning. From the results of observations carried out by researchers, one of the schools that is obliged to implement environmental education in science and social studies learning is SMPN 23 Kota Tangerang Selatan. Educators have difficulty implementing environmental education in science learning experiencing difficulties due to limitations in the availability of learning media to support learning activities, especially during the current Covid-19 Pandemic. Therefore, educators as facilitators can prepare in providing teaching materials that function as supporting books that have been serving as the main learning media for students.

After the information collection activities were carried out, the researchers found a problem, namely the lack of interesting teaching materials that could have an impact on increasing the motivation of students in online learning activities during the pandemic. Seeing the problems that occur, the researchers took the initiative to develop learning materials based on infographics assisted by Instagram as digital learning materials that can increase student motivation. Especially in online learning during the Covid-19 pandemic. Based on the information obtained in this research process, researchers will produce and develop digital learning material based infographic by Instagram.

Before conducting trials with students, firstly the product must be subjected to expert validation. Validation was carried out by three experts, are validation of media experts, validation of material experts and validation of educators as teachers. The score obtained from the results of the validation by media experts is 3.53 with the criteria "Very Valid". Suggestions given by media experts are written writing that must be tidied up and slightly enlarged so that it can be read clearly, and the use of colors is made more contrasting so that it is interesting and helps in facilitating students' understanding of writing that must be tidied up and slightly enlarged. The score obtained from the validation results by material experts is 3.70 with the criterion "Very Valid". The advice given by material experts is to include all sub topics related to the implementation of environmental education in science learning. Then the assessment of grade 7 educators resulted in a score of 3.75 with the criteria "Very Valid". The 
advice given by the class teacher is that interactive activities in the comments column are made more conducive so that educators do not have difficulty correcting student answers.

Before and after implementing infographic-based environmental education teaching materials assisted by Instagram, students filled out the ARCS learning motivation instrument that had previously been validated. The instruments that have been done by students are then processed to determine the motivation of students. The following is a grid of ARCS motivational instruments:

Table 2. ARCS Motivation Instrument Grid

\begin{tabular}{|c|c|c|c|}
\hline Aspek & Indikator & $\begin{array}{c}\text { Item } \\
\text { Statement }\end{array}$ & Total \\
\hline \multirow{2}{*}{ Attention } & $\begin{array}{l}\text { Student interest in learning environmental } \\
\text { education }\end{array}$ & $1,2,17$ & \multirow{2}{*}{5} \\
\hline & $\begin{array}{l}\text { Student activeness in environmental education } \\
\text { learning activities }\end{array}$ & 3,4 & \\
\hline \multirow{2}{*}{ Relevance } & $\begin{array}{lll}\text { Implementing Environmental } & \text { Education by } \\
\text { learning Natural Sciences } & & \\
\end{array}$ & $5,6,18$ & \multirow{2}{*}{5} \\
\hline & $\begin{array}{l}\text { Implementing environmental education with } \\
\text { daily activities }\end{array}$ & 7,8 & \\
\hline \multirow{2}{*}{ Confidence } & $\begin{array}{l}\text { Student confidence in environmental education } \\
\text { learning activities }\end{array}$ & 9,10 & \multirow{2}{*}{5} \\
\hline & $\begin{array}{l}\text { Have a high sense of competitiveness in } \\
\text { environmental education learning activities }\end{array}$ & $11,12,19$ & \\
\hline \multirow{2}{*}{ Satisfaction } & $\begin{array}{l}\text { Student satisfaction in using Instagram-based } \\
\text { infographic-based environmental education } \\
\text { teaching materials Having a sense of wanting to } \\
\text { develop in Environmental Education learning }\end{array}$ & 13,14 & \multirow{2}{*}{5} \\
\hline & $\begin{array}{l}\text { Student satisfaction in using Instagram-based } \\
\text { infographic-based environmental education } \\
\text { teaching materials Having a sense of wanting to } \\
\text { develop in Environmental Education learning }\end{array}$ & $15,16,20$ & \\
\hline
\end{tabular}

Figure 1.Percentage diagram of student motivation based on the ARCS
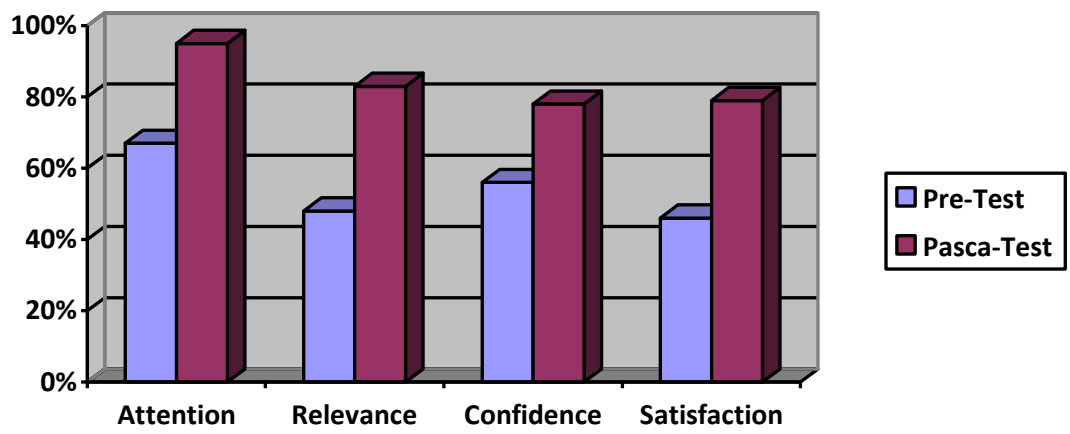

Student learning motivation is processed based on 4 aspects of the ARCS instrument, namely Attention, Relevance, Confidence, and Satisfaction. In the first motivation aspect, Attention, when before using the developed teaching materials it had an assessment percentage score of $67 \%$, after using the developed teaching 
materials there was an increase to $95 \%$. Furthermore, the percentage increase in motivation is associated with the n-gain criterion so that a score of 0.66 is in the moderate category. The second motivation aspect is Relevance, when before using the developed teaching materials it had an assessment percentage of $48 \%$ and after using the developed teaching materials there was an increase to $83 \%$. Furthermore, the percentage increase in motivation is associated with the n-gain criterion so as to obtain a score of 0.72 which is categorized as high. The third motivation aspect is Confidence, when before using the developed teaching materials it had an assessment percentage of $56 \%$ and after using the developed teaching materials there was an increase to $78 \%$. Furthermore, the percentage increase in motivation is associated with the n-gain criterion so that a score of 0.59 is in the moderate category. The fourth motivation aspect is Satisfaction, when before using the developed teaching materials it had an assessment percentage of $46 \%$ and after using the developed teaching materials there was an increase to $79 \%$. Furthermore, the percentage increase in motivation is associated with the n-gain criterion so that a score of 0.69 is in the moderate category.

Figure 2. Views on Environmental Education Instagram Posts
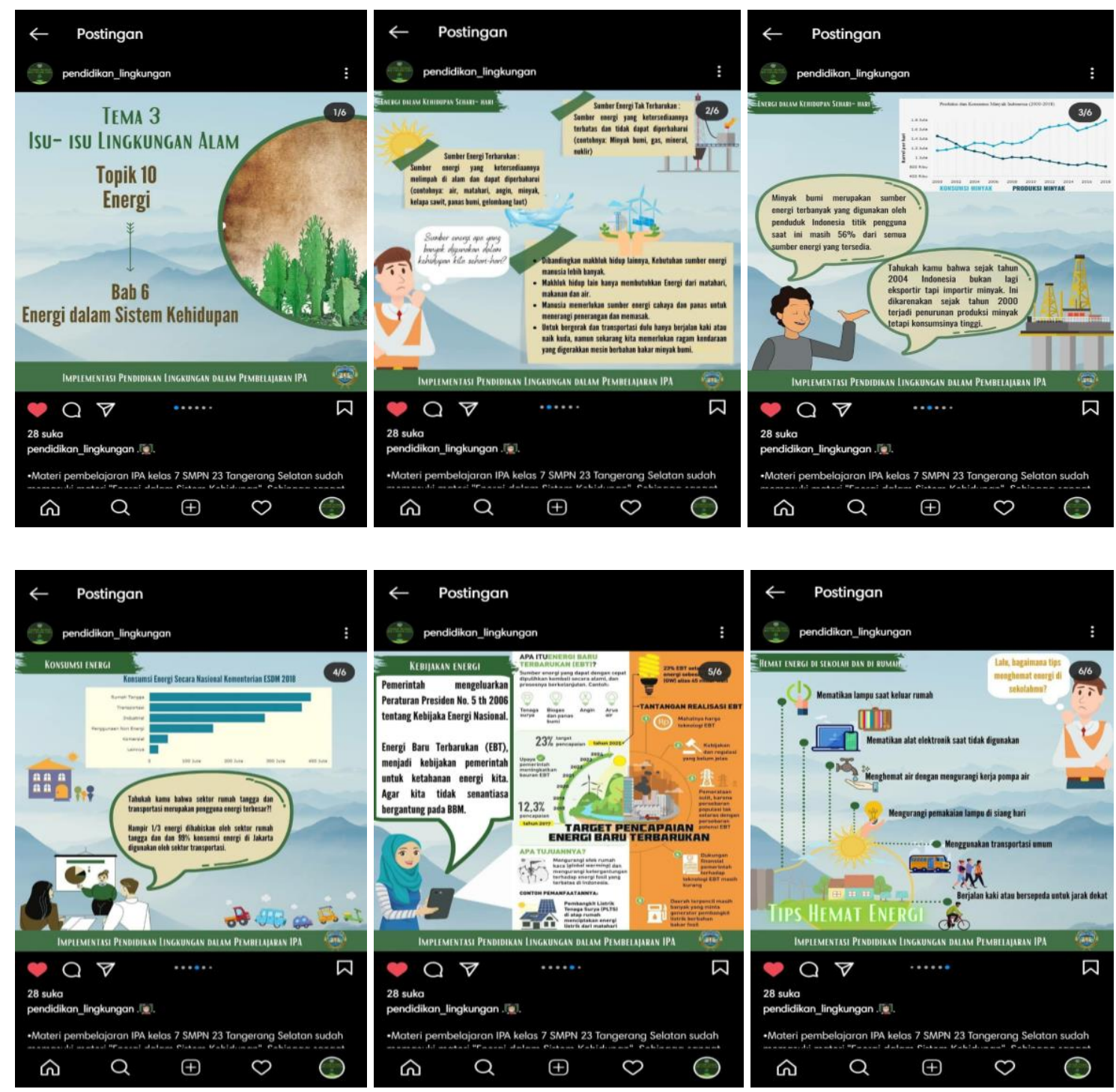
The results of this study indicate that Digital Teaching Materials on Instagrambased infographic-based environmental education teaching materials can help in increasing student motivation. Student motivation is needed in learning activities, especially during the Covid-19 pandemic. There has been a drastic change in learning activities that were originally carried out in offline schools to online-based learning activities. Instagram-based learning activities are an effort to increase student motivation. This is supported by the activeness of young students on social media on the Instagram page.

The implementation of environmental education, which has recently emphasized a lot of science and social studies learning materials, is a new challenge for educators in developing learning media as digital teaching materials to support learning activities. The existence of this research, can help educators in developing media and teaching materials in the process of teaching activities online during the Covid-19 pandemic and can also be implemented during the new normal period.

Other finding, for insatance McKiernan (2011) pointed out various differences in teaching material contents, learning channels, and practice methods between traditional teaching and digital learning. For instance, learning contents focusing on convenience and flexibility were suitable for digital learning, while traditional teaching was better for courses which required practical operation or teamwork. Although digital learning could not completely replace traditional teaching, it could achieve the best teaching effect and have learners be glad to learn by reinforcing traditional teaching with digital learning and comprehensively practicing both methods in teaching activity. Yien et al. (2011) pointed out the difference between digital learning and traditional teaching in learning environment and persons. Traditional teaching, with "lecture" in classrooms, was the most traditional and representative teaching method. In short, it referred to instructors delivering teaching materials in the teaching activity to learners through interpretation. With the long history, it has been broadly applied and is still one of favorable teaching methods of instructors.

Sebastian et al. (2012) regarded digital learning as the learning mode the most rapidly developed in past years as well as the learning mainstream in the future. In addition to the time background, it was rapidly developed because it broke through traditional teaching modes and presented various strengths. Miyoshi et al. (2012) organized the advantages of digital learning for the comparison with traditional teaching. Learning no problem: Digital learning allowed learners not being restricted on time and space as traditional learning so that learners could select the time and location for online learning and had no pressure and obstacle of time and space through the instructors' online interaction mechanis (Lin, M. H., Chen, H. C., \& Liu, K. S. 2017; Jude et al., 2014). Rich network resources: The Internet covers rich and diverse information that learners could acquire data simply by searching key words. When a digital learning platform was able to organize relevant resources for the use or connection of learners, network resources would be effectively applied through digital learning, and instructors or learners could acquire richer information beyond teaching materials in the curriculum to enhance the learning effect (Schneider, et al., 2018; Im et al., 2011).

Moreover, digital teaching platforms would provide interactive functions like chat room and discussion for more two-way communication between learners and instructors and among learners (Hockly, 2012; Hawlitschek, A., \& Joeckel, 2017). Reduction of teaching costs: The teaching material contents utilized in a digital 
teaching platform were kept as digital files that the completed teaching materials could be repeatedly utilized. In other words, the teaching material contents made by instructors before lessons allowed learners using for several times and learning repeatedly. Traditional teaching required all learners gathering at the same time and same place for the instruction that the teaching costs were increased.

\section{CONCLUSIONS}

Based on the results of this study, it can be concluded that the Digital Learning Material for Instagram-based infographic-based environmental education teaching materials: Its validity has been tested by experts. The validity test by media experts has a score of 3.53 criteria "Very Valid", material experts with a score of 3.53 criteria "Very Valid" and class teachers with a score of 3.70 criteria "Very Valid". The total average score of the validity test was 3.75 with the criteria "Very Valid". It has been tested effectively because the development of digital teaching materials can increase the learning motivation of 7 th grade students of SMPN 23 South Tangerang City in implementing environmental education into science learning. The increase in motivation can be seen from the ARCS aspect with an increase in the percentage score from $54 \%$ to $83 \%$. Classically, the increase in learning motivation can be seen by correlating the gain normalization of 0.67 with the "moderate" criteria.

\section{ACKNOWLEDGEMENTS}

Thank you to all participants, 7th grade students of SMPN 23 South Tangerang and experts who have helped in the continuity of this research activity.

\section{AUTHOR CONTRIBUTION STATEMENTS}

First author had contribution for collecting data in this research. Corresponding author was a corresponding person with editor, from submission until publish for this article. Another authors help to improve this research paper before submit to journal.

\section{REFERENCES}

Abel, T., \& McQueen, D. (2020). The COVID-19 pandemic calls for spatial distancing and social closeness: not for social distancing! In International journal of public health. https:/ / doi.org/10.1007/ s00038-020-01366-7

Ali Sadikin, A. H. (2020). Pembelajaran Daring di Tengah WabahCovid-19(Online Learning in the Middle of the Covid-19 Pandemic). BIODIK: Jurnal Ilmiah Pendidikan Biologi.

Bandyopadhyay, S. (2020). Coronavirus Disease 2019 (COVID-19): we shall overcome. Clean Technologies and Environmental Policy, 22(3), 545-546. https:// doi.org/10.1007/s10098-020-01843-w

Basilaia, G., \& Kvavadze, D. (2020). Transition to Online Education in Schools during a SARS-CoV-2 Coronavirus (COVID-19) Pandemic in Georgia. Pedagogical Research. https:// doi.org/10.29333/pr/7937

Bestari, A. C. Y., Faiza, D., \& Mayekti, M. H. (2020). Instagram Caption As Online Learning Media On The Subject Of Extended Writing During Pandemic Of Covid19. Surakarta English and ..., 3(1), 9-21. http:/ / ejournal.unsa.ac.id/index.php/selju/article/view/359

Bystrova, T. (2020). Infographics As a Tool for Improving Effectiveness of Education. KnE Social Sciences. https:/ / doi.org/10.18502/kss.v4i13.7710

Cahyani, A., Listiana, I. D., \& Larasati, S. P. D. (2020). Motivasi Belajar Siswa SMA 
pada Pembelajaran Daring di Masa Pandemi Covid-19. IQ (Ilmu Al-Qur'an): Jurnal Pendidikan Islam. https:/ / doi.org/10.37542/iq.v3i01.57

Gall, M. D., Gall, J. P., \& Borg, W. R. (2006). Educational Research: An Introduction, 8th Edition. Educational An Introduction.

Guo, B., \& Li, H. (2020). Guidance Strategies for Online Teaching during the COVID-19 Epidemic: A Case Study of the Teaching Practice of Xinhui Shangya School in Guangdong, China. SSRN Electronic Journal. https:// doi.org/10.2139/ssrn.3565627

Hawlitschek, A., \& Joeckel, S. (2017). Increasing the effectiveness of digital educational games: The effects of a learning instruction on students' learning, motivation and cognitive load. Computers in Human Behavior, 72, 79-86.

Hockly, N. (2012). Substitute or redefine? Modern English Teacher, 21(3), 40-42

Ichsan, I. Z., Hasanah, R., Aini, S., Ristanto, R. H., \& Miarsyah, M. (2019). Higher order thinking skills assessment based on environmental problem (hots-aep): mendesain evaluasi pembelajaran abad 21. Jurnal Biotek.

Iman, M. (2020). Pengguna Instagram di Indonesia Didominasi Wanita dan Generasi Milenial. In Goodnewsindonesia.Com.

Im, I., Hong, S., \& Kang, M. S. (2011). An international comparison of technology adoption testing the UTAUT model. Information \& Management, 48(1), 1-8.

Jayani, D. H. (2020). 10 Media Sosial yang Paling Sering Digunakan di Indonesia. Databoks; Katadata.Co.Id.

Juliyanto, E., \& Rusdi, F. (2019). Strategi Penyampaian Informasi Melalui Instagram Dengan Tampilan Infografis (di Kementerian Perdagangan RI). Prologia. https:// doi.org/10.24912/pr.v2i2.3591

Jude, L. T., Kajura, M. A., \& Birevu, M. P. (2014). Adoption of the SAMR model to assess ict pedagogical adoption: A case of Makerere University. International Journal of e-Education, e-Business, eManagement and e-Learning, 4(2), 106-115.

König, J., Jäger-Biela, D. J., \& Glutsch, N. (2020). Adapting to online teaching during COVID-19 school closure: teacher education and teacher competence effects among early career teachers in Germany. European Journal of Teacher Education. https:// doi.org/10.1080/02619768.2020.1809650

Lin, M. H., Chen, H. C., \& Liu, K. S. (2017). A study of the effects of digital learning on learning motivation and learning outcome. Eurasia Journal of Mathematics, Science and Technology Education. https:/ / doi.org/10.12973/eurasia.2017.00744a

Listya, A. (2018). Konsep dan Pengunaan Warna dalam Infografis. Jurnal Desain. https:// doi.org/10.30998/jurnaldesain.v6i01.2837

Mansur, H., \& Rafiudin, R. (2020). Pengembangan Media Pembelajaran Infografis untuk Meningkatkan Minat Belajar Mahasiswa. Jurnal Komunikasi Pendidikan. https:// doi.org/10.32585/jkp.v4i1.443

McKiernan, G. (2011). Configuring the 'Future Textbook'. Search, 19(4), 43-47.

Miyoshi, M., \& Tsuboyama-Kasaoka, N. (2012). School-based "Shokuiku" program in Japan: Application to nutrition education in Asian countries. Asia Pacific Journal of Clinical Nutrition, 21(1), 159-162.

Nieto-Márquez, N. L., Baldominos, A., \& Pérez-Nieto, M. Á. (2020). Digital teaching materials and their relationship with the metacognitive skills of students in primary education. Education Sciences. https:/ / doi.org/10.3390/educsci10040113

Rasmitadila, Aliyyah, R. R., Rachmadtullah, R., Samsudin, A., Syaodih, E., Nurtanto, M., \& Tambunan, A. R. S. (2020). The perceptions of primary school teachers of online learning during the covid-19 pandemic period: A case study in Indonesia. 
Journal of Ethnic and Cultural Studies, 7(2), 90-109. https:// doi.org/10.29333/ejecs/388

Ria, S., Siregar, S., Sirumapea, A., \& Ibrahim, M. Y. (2018). Buku Infografis “ Menjaga Kelestarian Lingkungan " Untuk Menanamkan Sikap Peduli Lingkungan Pada Anak - Anak. Jurnal SISFOTEK Global.

Rohim, A. M., \& Yulianti, D. (2020). Pembelajaran Fisika Berbantuan Aplikasi Instagram untuk Meningkatkan Motivasi dan Hasil Belajar Siswa. UPEJ Unnes Physics Education Journal, 9(2), 149-157. https:// doi.org/10.15294/upej.v9i2.41921

Sugiyono. (2012). Metode Penelitian Kuantitatif, Kualitatif dan R \& D.Bandung:Alfabeta. Metode Penelitian Kuantitatif, Kualitatif Dan $R \quad \mathcal{E}$ D.Bandung:Alfabeta. https://doi.org/10.1017/CBO9781107415324.004

Schneider, S., Nebel, S., Beege, M., \& Rey, G. D. (2018). The autonomy-enhancing effects of choice on cognitive load, motivation and learning with digital media. Learning and Instruction, 58, 161-172.

Umami, M. R., \& Budi, S. (2016). Pengaruh Media Infografis Dan Poster Pada Pembelajaran Joyful Learning Terhadap Prestasi Semester Gasal Sma Negeri Gondangrejo. 5(3), 9-17.

Wang, Y., Di, Y., Ye, J., \& Wei, W. (2020). Study on the public psychological states and its related factors during the outbreak of coronavirus disease 2019 (COVID-19) in some regions of China. Psychology, Health and Medicine. https:// doi.org/10.1080/13548506.2020.1746817

Wulandari, V., Abidin, Z., \& Praherdhiono, H. (2019). Pengembangan Media Pembelajaran E-Book Infografis Sebagai Penguatan Kognitif Siswa X MIA. Jurnal Kajian Teknologi Pendidikan.

Yien, J. M., Hung, C. M., Hwang, G. J., \& Lin, Y. C. (2011).A game-based learning approach to improving students' learning achievements in a nutrition course. Turkish Online Journal of Educational Technology, 10(2), 1-10

Zwart, D. P., Van Luit, J. E. H., Noroozi, O., \& Goei, S. L. (2017). The effects of digital learning material on students' mathematics learning in vocational education. Cogent Education. https://doi.org/10.1080/2331186X.2017.1313581

Copyright Holder :

(C) Rahmawati, H., Ristanto, R., \& Miarsyah, M.. (2021)

First Publication Right :

(C) IJoASER (International Journal on Advanced Science, Education, and Religion)

This article is under:

CC BY SA 